\title{
The Influence of Brazilian Biodiversity on Searching for Human Use Pharmaceuticals
}

\author{
David J. Newman
}

\author{
Newman Consulting LLC, 664 Crestwood Road, 19087 Wayne-PA, USA
}

\begin{abstract}
This relatively short review will cover the history of some potential drug entities whose beginnings were from Brazilian flora and fauna that led to scientific findings many years later that could not even have been thought of at the time of their initial discovery. The first two are the discoveries of the effects of peptidic toxins from the highly poisonous snake Bothrops jararaca upon the control of bradykinins that led to the angiotensin converting enzyme inhibitors, and the identification of pederin from the blister beetle Paederus species that 50 plus years later led to brand new discoveries as the source of many marine sponge metabolites. All occurred well before the Convention on Biological Diversity (CBD), in 1992. Then come discussions on lapachol and its congeners and then the potential for the investigation of microbes that are associated with insects, plants and marine invertebrates and their control of the syntheses of novel metabolites with pharmaceutical potential. The review finishes with comments on the biodiversity programs that São Paulo State has put in place and how they are materially aiding in investigations of Brazilian flora and fauna but under conditions that are CBD-compliant.
\end{abstract}

Keywords: biodiversity, biodiscovery, insect-microbe interaction, plant-microbe interaction, marine microbe

\section{Introduction}

Brazil has a land mass in the continent of South America, that covers over 8.5 million square kilometers and is approximately 4,500 kilometers North to South and also East to West, and is effectively the $5^{\text {th }}$ largest country in the World. Within its borders, the Amazon is the largest rain forest in the world but the country also has rolling plains and mountainous areas, so the flora and fauna are extremely varied on the gross scale, with incalculable numbers of insects and microbes existing in very different habitats.

Although the country's biological resources aside from macro-agriculture related to rubber, coffee, soybeans and sugar, have scarcely been investigated, there are some excellent examples where Brazilian biodiversity has led to discoveries within Brazil and then world-wide, that have led to novel agents directed against a number of human diseases, none of which would have occurred without the initial findings from Brazilian flora and fauna.

It is not the intention to "visit any of the situations" that occurred or may have occurred as a result of discoveries made before the 1992 Rio Earth Summit that led to the Convention on Biological Diversity (CBD), as this review

*e-mail: djnewman664@ verizon.net is not designed to discuss the politics, but the science involved. Today, with the CBD and successor documents in place and signed/ratified by all countries with the notable exception of the USA, discoveries made in Brazil from investigations of its flora and fauna are now covered by suitable agreements as to benefit sharing, etc.

It will be shown examples from the middle 1900s onwards that led to the angiotensin converting enzyme (ACE) inhibitors, the influence of the Amazonian blister beetle that ultimately led to the recognition of as yet unculturable microbes as the source(s) of such compounds, the work around lapachol and the very current work involving Brazilian and US investigators working in a very close partnership that is leading to significant discoveries in the interplay of microbes and insects, which may well lead to novel antibiotics and potential anti-tumor agents. Obviously there are many other examples that can be used, but these has been selected as they demonstrate the very long-term thought processes that have to be made and also how discoveries in one biological "field" influence others in what at the time appeared to be totally unrelated.

\section{Angiotensin Converting Enzyme Inhibitors (ACE-Inhibitors)}

The origin of this system (the renin-angiotensin system 
or RAS) dates back to a paper in $1884^{1}$ on the toxic properties of urine, followed 14 years later in 1898 in a paper by Tigerstedt and Bergman ${ }^{2}$ discussing renin. Work in the next 30 plus years led to the identification of kallikrein in urine and the discovery that neither kallikrein nor renin were vasoactive, but both released mediators from plasma. Skeggs et al. ${ }^{3}$ then reported in the middle 1950s that renin liberated a decapeptide (angiotensin I) which is converted to the active peptide (angiotensin II) in the presence of chloride ions by a factor present in horse plasma, that was named as angiotensin converting enzyme.

In the early 1960s, Ferreira, who was an associate of Rocha e Silva at the University of São Paulo, joined the Vane laboratory in London (Vane had worked on the whole renin enzyme complex). Ferreira and Rocha e Silva ${ }^{4}$ had shown in 1962 that the enzyme was a zinc metalloproteinase and was inhibited by mercapto derivatives. Working with Vane, Ferreira discovered that substances (now known to be peptides) from the venom of the Brazilian snake, Bothrops jararaca potentiated the effect of bradykinin on smooth muscles and also inhibited the inactivation of bradykinin. The first inhibitor was a pentapeptide (1) which was a slow substrate of ACE. ${ }^{5}$ This was rapidly followed by the isolation and then the total synthesis of the nonapeptide teprotide (2). ${ }^{6}$ This had an ACE-resistant proline-proline C-terminus and just to demonstrate how similar findings occur much more frequently than is usually realized, in 1970, a Japanese group isolated a bradykinin-potetiating peptide from the Japanese snake, Agkistrodon halys blomhoffii. ${ }^{7}$
The data from teprotide and other peptides from the snake venom studies in Vane's laboratory then returned to the Western hemisphere, but this time, North of the Equator, and became the scientific impetus for the synthesis of what can legitimately be considered the first rationally designed drug entity, approved under the name of Captopril ${ }^{\circledR}(\mathbf{3})$ for the treatment of hypertension in man. The group at Squibb in the USA chose to use carboxypeptidase A as their model for testing their synthetic molecules. This was a rather lucky choice as later work including the crystal structure of the ACE "C-domain" demonstrated that the three-dimensional structure is not related to carboxypeptidase A; rather it resembles neprilysin. ${ }^{8}$ However, carboxypeptidase A is a zinc-metallodipeptidase and functionally imitates ACE, so all was well. In Scheme 1 the cascade that demonstrates the relationship amongst these enzymes/peptides in man is shown.

Following on from captopril, in particular, the work by Patchett et al. ${ }^{9}$ led to the development of enalaprilat (4) and lisinopril (5). Inspection of these structures definitively show their "background in natural products" as they resemble the tripeptides Phe-Ala-Pro and Phe-Lys-Pro, respectively. Five years later, Patchett and Cordes ${ }^{10}$ published a much fuller record of the design work and biology around the ACE-inhibitors, which should be consulted for information.

In the same relative time frame, protein chemists/ biochemists began to interrogate the structure of ACE and to their surprise, discovered that crystalline ACE had two

Angiotensinogen

a2 Globular Protein
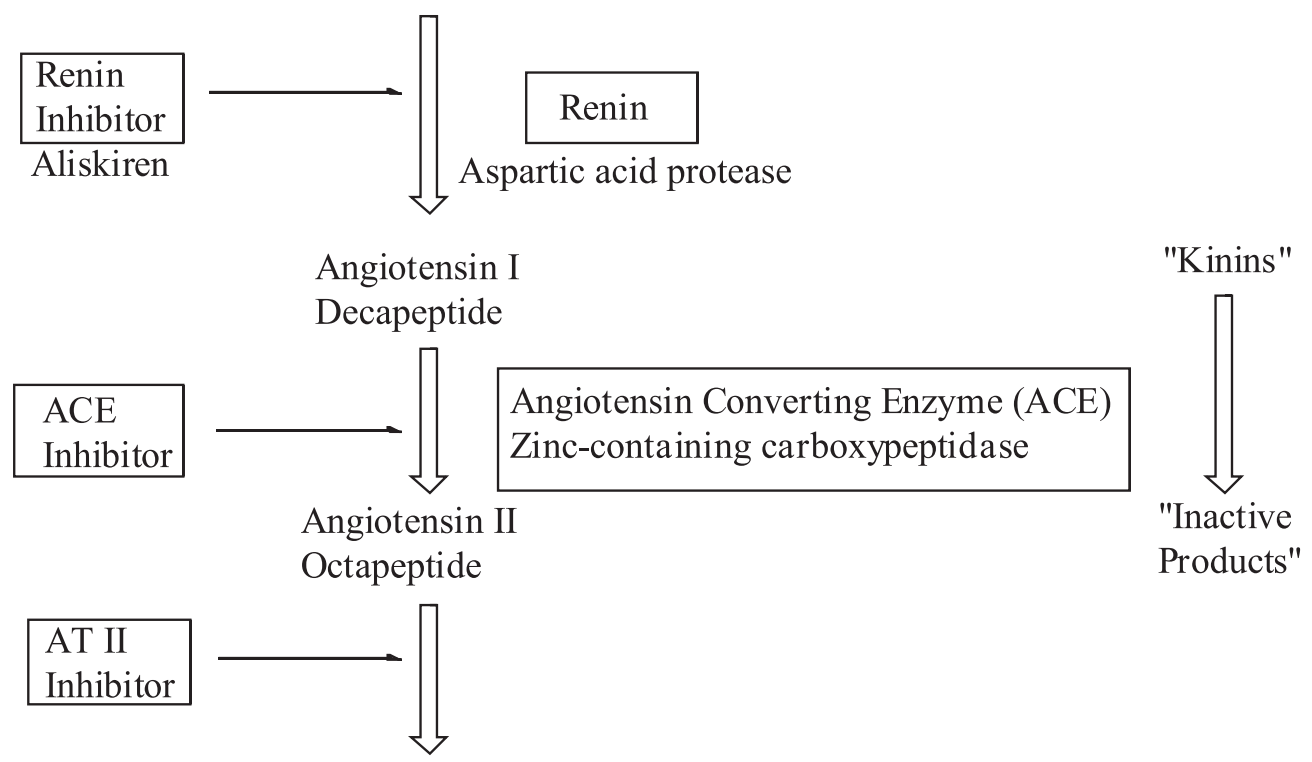

Angiotensin II Receptor

Scheme 1. The angiotensin-renin cascade. 
internal areas of homology covering around 600 residues when their amino acid sequences were determined. Thus there are two distinct domains that are named as the ACE N-domain and ACE C-domain. These are roughly $60 \%$ homologous when amino acid sequences and deoxyribonucleic acid (DNA) sequences are compared. If one compares the catalytic sites then $89 \%$ homology is shown in the "core catalytic site" regions. These two sites have quite different "affinities" as measured by inhibition constants. Thus captopril was found to be modestly $\mathrm{N}$-selective whereas the next series, lisinopril and enalaprilat are more $\mathrm{C}$-selective. If one then used the phosphinic tetrapeptide RXPA380 (6), it is 3,000 times more selective for the $\mathrm{C}$-domain versus the phosphinic tetrapeptide RXP407 (7) is a 1,000 fold more N-domain selective. ${ }^{11}$ Later work reported by Danilov et al. ${ }^{12}$ in 2011 demonstrated the relationship in mature human ACE.
However, in the last few years it has become obvious that there exists at least one other ACE, known as ACE2. This is an exopeptidase that catalyzes the conversion of angiotensin (Ang) I to the nonapeptide Ang 1-9 (8), or the conversion of Ang II to Ang 1-7 (9). ${ }^{13,14}$ ACE2 appears to be a chimeric protein formed by duplication of two genes and there are ancient orthologs found in the tunicate (sea squirt) Ciona intestinalis and in the primitive chordate amphioxus Branchiostoma floridae. What is also of significant import from a disease perspective is that ACE2 is the receptor protein for the SARS virus. ${ }^{15}$ Finally for a thorough discussion of the status of ACE and its inhibitors as of the end of 2012, the excellent review by Bernstein et al. ${ }^{16}$ should be consulted, to which should be added the 2014 review by Regulska et al ${ }^{17}$ where more information on quantitative structure-activity relationship (QSAR) properties are discussed with respect to newer agents.

$$
\text { Pyr-Lys-Trp-Ala-Pro-CO }{ }_{2} \mathrm{H}(\mathrm{SQ} 20475)
$$

\section{Pentapeptide}<smiles>CC(CS)C(=O)N1CCCC1C(=O)O</smiles>

3. Captopril

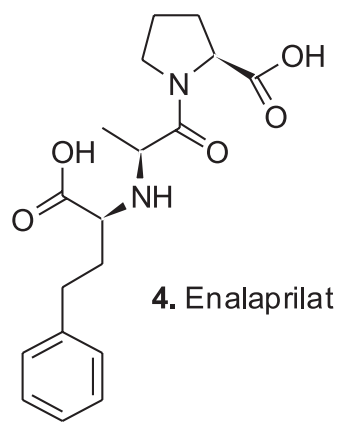<smiles>O=C(NC(c1ccccc1)P(=O)(O)C1CCCC1C(=O)NC(Cc1cc2ccccc2[nH]1)C(=O)O)Oc1ccccc1</smiles>

6. RXPA380

\section{Pyr-Trp-Pro-Arg-Pro-GIn-lle-Pro-Pro- $\mathrm{CO}_{2} \mathrm{H}$ (SQ 20881)}

\section{Teprotide}<smiles>NCCCCC(NC(CCc1ccccc1)C(=O)O)C(=O)N1CCCC1C(=O)O</smiles><smiles>CC(=O)NC(CC(=O)O)C(=O)NC(Cc1ccccc1)P(=O)(O)CC(C)C(=O)NC(C)C(N)=O</smiles>

7. $\mathrm{RXP} 407$

$\mathrm{H}_{2} \mathrm{~N}$-Asp-Arg-Val-Tyr-lle-His-Pro- $\mathrm{CO}_{2} \mathrm{H}$

9. Ang 1-7

Figure 1. Compounds 1 to $\mathbf{9}$; leads to, and ACE inhibitors. 
Thus the discovery made by Brazilian pharmacologists and physicians of the activity of small peptides from the venom of Bothrops jaracaca, in the bradykinin system, has come a series of extremely important antihypertensive drugs, but have also led to a much more nuanced appreciation of what the original target protein was thought to do and what it actually does in many biological systems. The protein is extremely ancient and has been found in one form or another in all taxonomic kingdoms.

\section{Brazilian Paederus Beetles and Marine Sponge Metabolites}

The reader might well wonder why the insect Paederus fuscipes, which is very well-known in the Brazilian jungle as emitting a very toxic "spray" when attacked/startled is linked with materials isolated from a variety of marine sponges of varied taxonomy and geographic locations. Hopefully the linkage will become apparent as this section continues.

The structure of the toxin pederin (10) "used" by rove beetles of the genus Paederus was first identified chemically by Italian scientists studying this genus with a publication in $1952 .{ }^{18}$ It should be pointed out at this stage that this genus is found on all continents except Antarctica and the dermatitis caused by the toxin has been well described in the literature, with the recent publication by Cressey et al. ${ }^{19}$ being well worth reading as it demonstrates the problem with this toxin.

Following on from the original 1952 publication, Cardani et al. ${ }^{20}$ in 1965 published an initial structure which was then revised three years later by Matsumoto et al. ${ }^{21}$ and is the structure shown above (10). This is where it might well have languished as simply being an interesting molecule to synthesize as an example of novel chemistry. This can be seen in some relatively recent publications in the synthetic chemistry literature. ${ }^{22,23}$ However, in the late 1980s, Perry et al. ${ }^{24,25}$ at the University of Canterbury in New Zealand, published their finding that an extract of a relatively deep water sponge of the genus Mycale, collected in cold water, had a bioactive molecule that had antiviral and cytotoxic biological activities and a structure that contained the pederin nucleus. The two molecules were named mycalamide A (11) and B (12) differing only by a methyl group, but with a 10 fold difference in biological activity.

In 1981, though not dealing with a sponge source, Price et al. ${ }^{26}$ reported that chloramphenicol was found in an extract of the moon snail (Lunatia heros) collected in the Gulf of Maine. As far as we know, was the first confirmed report of a terrestrial-sourced antibiotic from a marine invertebrate. One year later, the Faulkner group at
Scripps Institute of Oceanography reported the isolation of renieramycins A (13) to D from the Eastern Pacific sponge, Reniera sp. Renieramycins had the base structure of the well-known and then current clinical candidates, such as saframycin A (14), isolated from the terrestrial microbe S. lavendulae. ${ }^{27}$

If one now asks "what is the relationship of such findings to pederin and Paederus beetles?" the following reports in the insect physiology literature will begin to uncover the reasons. In 1999, the German entomologist, Rupert Kellner, ${ }^{28}$ published an extremely interesting paper asking "what was the basis of pederin polymorphism in the rove beetle Paederus riparus?" His suggestion, with data, was that an endosymbiont was the actual producer of the toxin. Then two years later, he reported that pederin biosynthesis was suppressed by using antibiotics to remove endosymbionts in another species, Paederus sabaeus. ${ }^{29}$ Thus there was significant evidence implying a bacterial component to the production of pederin. Since this occurred in two different species of the beetle, it probably was common to all.

However, to bring the full story to its climax, one has to return to the marine environment, as in the years from 1988 to early 2000, a significant number of sponge extracts produced molecules such as the onnamides, with onnamide $\mathrm{F}$ being an example (15), ${ }^{30}$ and theopederins such as $\mathrm{K}$ and $\mathrm{L}(\mathbf{1 6}, \mathbf{1 7}) \cdot{ }^{31}$ Then, in 2002, Kellner ${ }^{32}$ identified the endosymbiont as a very close relative to Pseudomonas aeruginosa and showed that interspecific transmission of the endosymbionts was related to the different genetic makeup of individual isolates.

So how did this work then relate to the "marine pederins"? In a series of papers in the time frame from 2002 to 2005 , first Piel ${ }^{33,34}$ demonstrated that he could find the gene clusters in the putative pseudomonad identified and isolated by Kellner, that were the biosynthetic clusters for pederin, and that they had an unprecedented diversity of catalytic domains in the first four clusters in the process. Since Piel ${ }^{33,34}$ had the genetic probes, he then collaborated with the Japanese group led by Fusetani and Matsunaga (Piel et al. ${ }^{35}$ ) at the University of Tokyo to investigate the production of the closely related onnamides isolated from the Japanese sponge Theonella swinhoei (yellow variant). The pseudomonal probes "lit up" the sponge metagenome and they were able to locate the nexus of the biosynthesis to an as yet uncultivated symbiont. Concomitantly he also demonstrated evidence for what is now known as a "symbiosis island" that permitted horizontal acquisition of the pederin biosynthetic capabilities in Paderus fuscipes. ${ }^{36}$ The details as of that time were published in a short review in $2005 .{ }^{37}$ In 2011, Kador et al. ${ }^{38}$ then published 
oligonucleotide probes that could be used to detect pederin producers in Paederus beetles.

In 2013, Wilson and Piel $^{39}$ published a review demonstrating potential approaches to the study of uncultivated or not yet cultivatable microbes as resources for novel biosynthetic enzymology. This paper demonstrated the potential for performing genomic work on very small numbers of uncultivated bacteria isolated from invertebrate hosts, in this case, sponges and tunicates. This was the type of investigation that Bewley and Faulkner ${ }^{40}$ would love to have been able to perform in the late 1990s when they identified the production of the cyclic peptides swinholide A and theopalauamide by Theonella swinhoei and their indication that a microbial consortium might be responsible.

The year after the 2013 paper, Piel and co-workers ${ }^{41}$ demonstrated in a superb publication in Nature, that the producing organism in $T$. swinhoei was an as yet uncultured microbe that contained the necessary genetic machinery to produce 31 of the then 32 known cytotoxins isolated from this particular sponge. The details related to individual agents are still being published but the numbers were presented at an open seminar in Tel A'viv University in early 2014. It should be emphasized that not only were the compounds produced, but they were in fact ribosomal products that were then tailored by a novel series of enzymes expressed by the same microbe, not as previously thought to be produced by non-ribosomal protein synthesis. Interestingly the protein phosphatase inhibitor calyculin A (18) was also produced by this sponge, with data now published by Wakimoto et al..$^{42}$ demonstrating that it too was a product of the same uncultivated microbe.

Recently, Piel and co-workers ${ }^{43}$ have published the enzymology involved in the formation of the long peptides such as the polytheonamides which have repeating $D$ and $L$ aminoacids but are ribosomally produced peptides. This paper was followed by a review ${ }^{44}$ demonstrating the metabolic potential of the as yet uncultivated "Entotheonella" where more information is given as to the multiplicity of structures that result from this microbe. Finally there was a recent very intriguing report showing the presence of pederin-like compound, nosperin (19) in a lichen, so the genes are extremely widespread. ${ }^{45}$

As mentioned earlier, pederin certainly excited synthetic organic chemists and over the years, effectively all of the molecules that contain the pederin backbone, even when ring-opened as in irciniastatin (20), have been synthesized by considerable numbers of chemists. The following papers should be consulted by readers interested in the synthetic processes used..$^{22,23,46-52}$ Of these, the review by Mosey and Floreancig ${ }^{50}$ in 2012 gives a recent and relatively thorough overview of the isolation, biological activities and medicinal chemistry of these agents.

Thus what started as a discussion of the toxin produced by the blister beetle that was known in Brazilian forests/ jungles, led to the ability to identify and express genetic loci related to the biosynthesis of the agent, but then moved into areas not even thought to be possible; that the beetle toxin was in fact, used by "Mother Nature" (or biodiversity) to generate molecules in organisms as diverse as shallow and deep water marine sponges, warm and cold waters environments and even terrestrial lichens. None of these were even thought of in the wildest dreams of the original scientists working on beetle toxins irrespective of their geographic locations. Finally, in 2014, Vieira et al. ${ }^{53}$ published an interesting review covering rove beetles of medical importance in Brazil that should be consulted by people interested in the entomology aspects of this group.

\section{Microbial Symbioses in Insects and Marine Invertebrates}

In the previous sections were shown some of the results of looking at as yet uncultured microbes in one particular sponge, because the metabolites produced led back to a particular toxic beetle well known in Brazil. In this section however, there will be discussion of areas of biodiversity that are well represented in Brazil but are in general not well studied other than by a few investigators in specific areas, but have very significant opportunities for identifying agents that will be of great utility to the Brazilian populace.

These areas of biodiversity can be divided into insectmicrobe symbioses, and marine invertebrate-microbe symbioses. Each will be discussed with examples of what has been published in terms of novel agents.

\subsection{Insect-microbe symbioses}

The relationships between insects and microbes have been investigated in a variety of geographic areas (the Paederus beetle work in the mountains where Iran, Turkey and Iraq come together was discussed earlier) but what is relevant to Brazil are the reports, mainly from work performed by Clardy and Currie ${ }^{54}$ and their collaborators in the various countries that border Brazil and also from similar work in other distinct geographic areas. In these cases, the insect "farm" fungi as a food and have commensal bacteria that produce antifungal agents against attacking fungi.

In a recent report ${ }^{54}$ in 2014 on work with termites in South Africa, they reported that a Streptomyces isolate that was closely related to Streptomyces malaysiensis cultured from a South African nest of the termite 
<smiles>C=C1C[C@H]([C@H](O)C(=O)N[C@H](OC)[C@H]2C[C@H](O)C(C)(C)[C@@H](C[C@@H](COC)OC)O2)OC(C)C1C</smiles>

10. Pederin<smiles>COC1=C(C)C(=O)C2=C(C1=O)[C@@H]1[C@@H]3CC4=C(C(=O)C(OC)C(C)C4=O)[C@@H](CNC(=O)C(C)=O)N3[C@@H](C#N)C([C@H]2O)N1C</smiles>

14. Saframycin $A$

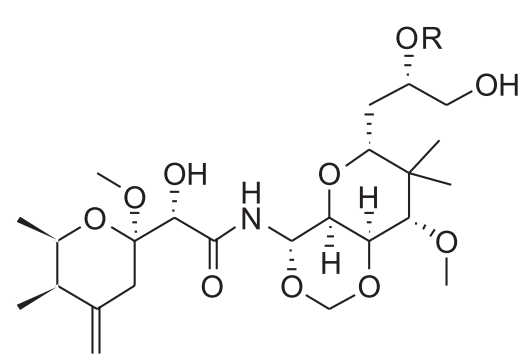

11. Mycalamide $A ; R=H$ 12. Mycalamide $B ; \mathrm{R}=\mathrm{CH}_{3}$<smiles>C=C1C[C@](OC)([C@H](O)C(=O)N[C@H](OC)[C@H]2C[C@H](OC)C(C)(C)[C@@H](C[C@@H](O)C/C=C\C=C\C(=O)O)O2)O[C@H](C)C1C</smiles>

15. Onnamide F<smiles>C/C=C(/C)C(=O)OCC1C2=C(C[C@H]3C4C(=O)C(OC)=C(C)C(=O)C5=C4N(C)C(CN13)C5O)C(=O)C(C)C(OC)C2=O</smiles>

13. Renieramycin $A$

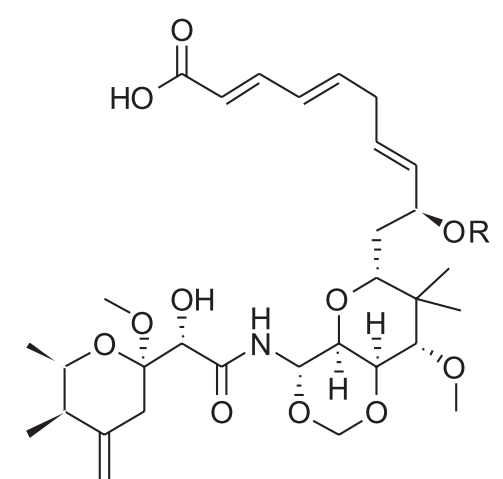<smiles>COCC([C@H](O)C(O)C(N)=O)N(C)C</smiles>

18. Calyculin A

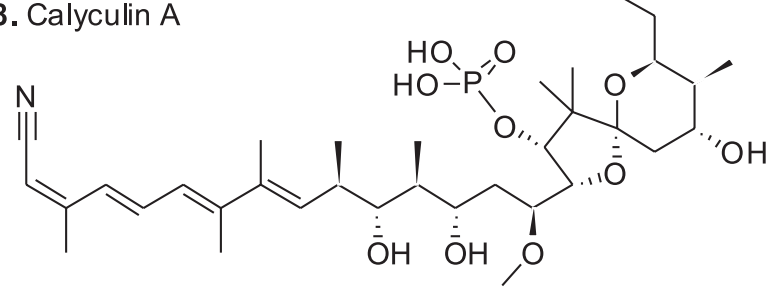

16. Theopederin $\mathrm{K} ; \mathrm{R}=\mathrm{CH}_{3}$ 17. Theopederin $\mathrm{L} ; \mathrm{R}=\mathrm{H}$<smiles>C=C1C[C@](OC)([C@H](O)C(=O)N/C=C/[C@@H](CO)[C@@H](O)[C@H](C)C(=O)N2CCC[C@H]2[C@H](O)CC(N)=O)OC(C)C1C</smiles>

19. Nosperin<smiles>C=C(C)C[C@H](OC)[C@H](O)C(=O)N[C@H](OC)[C@@H]1C[C@@H](O)C(C)(C)[C@@H]2C[C@H](O)[C@H]([C@H]3Cc4c(C)c(O)cc(O)c4C(=O)O3)O[C@H]21</smiles>

Figure 2. Compounds 10 to 20; pederin-related materials and calyculin A.

Macrotermes natalensis, produced a very potent antifungal agent that was a complex fused bicyclic ansa macrolide that was obviously based on geldanamycin biosynthesis but with a novel PKS modification. The compound was named natalamycin (21) and was only produced when the bacterium was grown on solid medium.

The fungus growing ants of the insect tribe known as the Attini have been extant for at least 50 Mya and originated 
in the Amazon. They subsequently evolved into greater than 200 species that are collectively the major herbivores of the "New World Tropics". Their typical agricultural, (fungal farm), system has a minimum of four components. The insects (ants), a fungal crop that is within the phylum Basidiomycota, a symbiotic bacterium which is within the Actinobacteria and a fungal pathogen (the "attacker") from the phylum Ascomycota. Because they maintain their fungal gardens by provision of plant material (usually leaves), their colloquial name is "leaf-cutting ants". The actinobacteria are usually maintained in specialized anatomical structures on the ant. The Clardy group ${ }^{55}$ had reported in 2009 on the discovery of a specific antifungal agent, dentigerumycin (22) from the actinobacteria associated with the ant (Apterostigma dentigerum), a Pseudonocardia sp. This class of molecules containing piperazic acids in the ring structure were well-known as potential antitumor agents, ( $c f$ the 2011 review by Oelke et al. $)^{56}$ but there were no previous reports from such a biological symbiotic source. In 2015, Clardy and co-workers ${ }^{57}$ published a very interesting follow-up to the dentigerumycin story using isolates from Apterostigma spp. and from the more highly derived Trachymyrmex cornetzi but looking for dentigerumycinlike molecules. They found three previously unidentified cyclic depsipeptides that they named gerumycins A-C (23-25), each containing three piperazines. These three molecules were 19-membered ring structures rather than the 18-membered ring in dentigerumycin. In addition, the gerumycins were at least 3 orders of magnitude less active against the Escovopsis fungus which is the predator of the ant's foodstuff. So the function of these molecules is not yet known. Interestingly, the gerumycins are more closely related to piperazimycins (26-28) which were isolated from a marine Streptomyces as antitumor agents. ${ }^{58}$ Using genomic data from the genomes of the producing organisms it appears that the biosynthetic gene clusters may well have evolved outside of these particular Pseudonocardia sp. The concept of pathogenic genomic islands is well described in the literature and how these may be acquired and removed. ${ }^{59}$

From a Brazilian perspective, this type of investigation is being actively followed by the joint program between FAPESP and the US Government funded International Cooperative Biodiversity Group (ICBG) that is studying the therapeutic agents from bacterial symbionts of Brazilian invertebrates with Jon Clardy from Harvard Medical School leading the US side and Monica Pupo in the Pharmacy School at the University of São Paulo, the Brazilian. ${ }^{60}$

In 2015, two papers ${ }^{61,62}$ were published that extended the insects from the ants and termite already referred to the Brazilian stingless bee Scaptotrigona depilis and a fungus of the Ascomycotina, a Monascus species. In this case, fungal mycelia inside the brood cell are eaten by the larvae. Though no biological activity was found in the small number of tests used, but when larvae were raised in vitro on sterilized food supplemented with the fungal mycelia, a 10 fold increase in viability was seen compared to larvae without fungal supplementation. The first paper described the overall process ${ }^{61}$ whilst the second was a discussion of that paper confirming that this was "fungal farming" and not a fortuitous occurance. ${ }^{62}$

In the insect-microbe axis, the very recent review by Beemelmanns et al. ${ }^{63}$ shows the variety of metabolites produced in these symbioses. This paper should be read in conjunction with two others that show how the Panamanian frogs which had experienced a lethal fungal infection, have now overcome the infection via commensal microbes. ${ }^{64,65}$ What was not mentioned however, is that these vertebrates contain toxins that almost certainly are adsorbed from their diet of specific ants.

\subsection{Marine invertebrate-microbe symbioses}

If one now looks at the marine environment of Brazil, what is striking is the relatively small number of Brazilian chemists who are actively involved in investigating the metabolites "produced/contained" in the marine invertebrates present. Brazil has the longest coast line in South America and it ranges from effectively the Equator to South of the Tropic of Capricorn. Depending upon the source, Brazil's coast line of approximately $30,000 \mathrm{~km}$ is almost the same as China and one third that of Indonesia. The Indonesian figure however, is skewed by the fact that it is over 13,000 islands, whereas Brazil and China effectively have only one coast. These figures are from the World Resources Institute. ${ }^{66}$ However, although the chemists are few in number, they have effectively embraced the microbial aspects of marine invertebrates in addition to reporting compounds isolated directly from invertebrate extracts.

From a microbial aspect, the papers that have been published by Thompson and co-workers ${ }^{67,68}$ over the years, have shown how relatively recently they have moved into studying the microbial consortia present in Brazilian marine invertebrate samples, with two recent excellent papers demonstrating the potential in investigations of the microbiome of the endemic Brazilian sponge Arenosclera brasiliensis. To these two reports should be added papers in $2012^{69}$ evaluating the potential of marine fungal metabolites as leads to drug candidates, which should be read in conjunction with an extensive review ${ }^{70}$ in 2014 of the potential of studying Brazilian microbes from a variety of sources. 


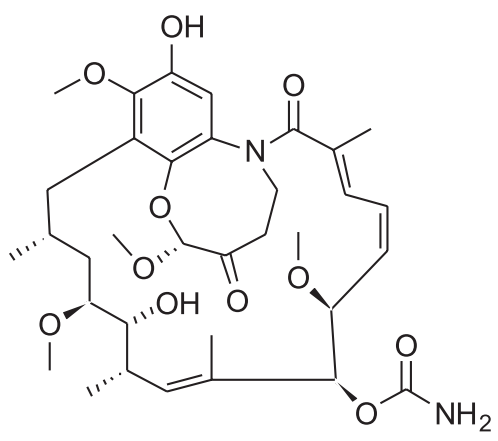

21. Natalamycin

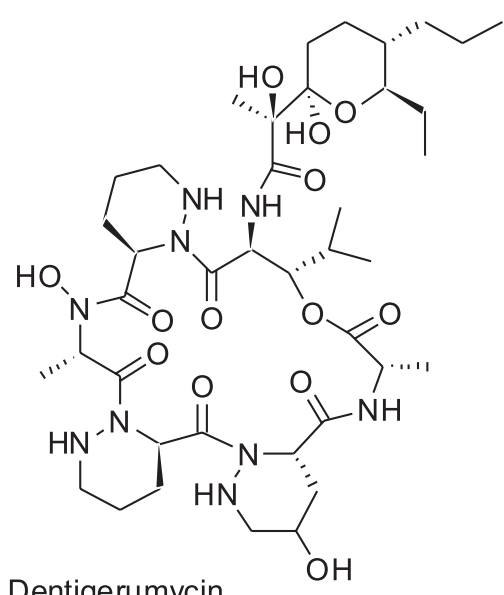

22. Dentigerumycin

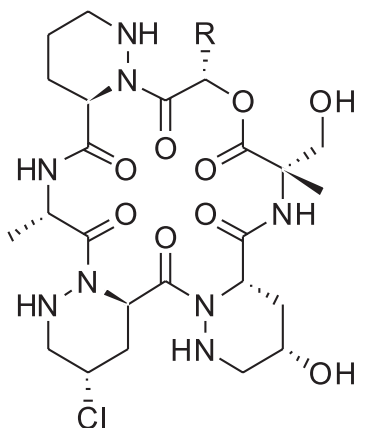

23. Gerumycin $A ; R=H$ 24. Gerumycin $B ; \mathrm{R}=\mathrm{CH}_{3}$<smiles>C[C@@H](CO)NC(=O)[C@H](C)NC(=O)C1CC(O)CNN1C(=O)COC(=O)[C@](C)(CO)NC(=O)[C@@H]1C[C@@H](O)CNN1C(=O)C1CC(Cl)CNN1C(=O)CO</smiles>

25. Gerumycin C



26. Piperazimycin $\mathrm{A} ; \mathrm{R} 1=\mathrm{OH}, \mathrm{R} 2=\mathrm{CH}_{3}$ 27. Piperazimycin $B ; \mathrm{R} 1=\mathrm{H}, \mathrm{R} 2=\mathrm{CH}_{3}$ 28. PiperazimycinC; R1 $=\mathrm{OH}, \mathrm{R} 2=\mathrm{CH}_{2} \mathrm{CH}_{3}$

Figure 3. Compounds $\mathbf{2 1}$ to $\mathbf{2 8}$; mainly from ant-microbe symbioses.

\section{Plant-Based Discoveries}

\subsection{General comments}

Brazil has a rich history of phytochemical investigation but for many years a major component of these studies was directed towards identification of plant metabolites and structure determination, with examples being the paper by Regasini $e t$ al..$^{71}$ and one published the previous year on chemical constituents of flowers from Pterogyne nitens also by Regasini et $a l . .^{72}$ To these can be added the excellent paper on the use of modern mass spectral techniques in determining chemical structures from Silva et al. ${ }^{73}$ More and more papers have been published where biological activities of isolated compounds were reported including the use of bioactivity driven isolation techniques. A recent example would be the report on the discovery of cytotoxic guanidine alkaloids from the same plant species as mentioned above. ${ }^{74}$ The 2013 review covering properties of compounds from the plant family Chrysobalanaceae by Carnevale Neto et al. ${ }^{75}$ in 2013 , demonstrated the

chemical/biological capacities of metabolites from this family of plants, though there was an element of structures first, biological activity second, in some of the examples cited.

\subsection{Lapachol and lapachone}

There is one particular plant compound series that has a very strong relationship to Brazil. Species of the genus Tabebuia (Bignoniaceae) have a history in the Amazonian region for the treatment of several diseases, including syphilis, fever, malaria, cutaneous infections and stomach disorders. Claims in the 1960s for clinical efficacy in the treatment of cancers, particularly in Brazil, led to widespread sales of the bark and trunk wood of several species (T. impetiginosa Mart. Ex DC Standl.(synonym T. avellanedae Lorentz ex Griseb), T. rosea Bertol., and T. serratifolia (Vahl) Nicholson) in health food stores under various names such as "pau d'arco" or "lapacho". Numerous bioactive compounds had been isolated, but the naphthaquinones, particularly lapachol (29), first isolated 
in 1882 from T. avellanedae, ${ }^{76}$ and $\beta$-lapachone (30) have been the most studied.

Observation of significant in vivo antitumor activity for lapachol in some early mouse models resulted in its advancement to clinical trials by the National Cancer Institute (NCI) in the 1970s, but the trials were terminated due to unacceptable levels of toxicity. ${ }^{77}$ Interest in $\beta$-lapachone (also known as ARQ 501 when the company ArQule put it into clinical trials) was prompted by its activity against a range of tumor cell lines, including breast, leukemia, and prostate lines and several multidrug- resistant lines. ${ }^{78}$ ARQ 501 had completed seven clinical trials (as of June 2016) against a range of solid tumors, including pancreatic cancer, in combination with gemcitabine, with data on three of the trials being presented as abstracts, one at the American Society for Cancer Research (AACR) meeting in 2006, ${ }^{79}$ and the other two at the American Society for Clinical Oncology (ASCO) meeting in 2007.80,81 An important variation, the water-soluble prodrug ARQ 761 which does not have a structure published to date, currently has two ongoing Phase I clinical trials that are recruiting for patients with solid cancers in one trial, and in conjunction with gemcitabine, directed against pancreatic cancer in the other. ARQ 761 is listed as being $\beta$-lapachone in a recent review by Wellington ${ }^{82}$ where he is discussing the anticancer activities of naphthoquinones. However, Arqule reports that it is a prodrug of $\beta$-lapachone. Recently a Chinese group published data on modifications of the base structure that might lead to drug entities with better pharmacological activities, ${ }^{83}$ with compound $3 \mathrm{k}(\mathbf{3 1})$ being their best molecule from a solubility and stability aspect. ${ }^{84}$ These two papers should be consulted by readers interested in how an initial structure from the late 1890s, may lead to novel pharmaceuticals around a 130 years later.

Lapachol, (29) which was first isolated from T. avellanedae in 1882 as mentioned earlier, was used for the treatment of malaria in the late $19^{\text {th }}$ century, and then later formed the model for the synthesis of atovaquone (32), which, in combination with proguanil hydrochloride, has proved effective in the treatment of malaria and is available in many countries under the trade name Malarone ${ }^{\circledR}$ for treatment of acute uncomplicated malaria caused by Plasmodium falciparum. ${ }^{85}$ Currently, as of June 2016, there are 3 clinical studies that are recruiting, and details of 16 now closed in the National Institutes of Health (NIH) clinical trials database. Atovaquone has also been shown to be effective for the treatment of mild and moderate P. carinii pneumonia, ${ }^{86}$ and, in combination with azithromycin, for the treatment of babesiosis, caused by Babesia microti, a tickborne, malaria-like infection that may cause severe illness and death and which is enzootic, mainly in southern New England, southern New York, Wisconsin and Minnesota. ${ }^{87}$ For readers who would like further information on lapachol and its congeners as anticancer agents, the 2014 review by Epifano et al. ${ }^{88}$ should be consulted.

Finally, as in the case of most of the agents discussed in this review, microbes appear again as possible source(s) for one of the natural products discussed in this section. Though lapachol as a substrate for biotransformation by fungi was reported as early as 1979 by the Otten and Rosazza $^{89}$ in 2014, a group in India at the Shridevi Institute of Engineering reported the isolation of a fungal endophyte, identified as a strain of Aspergillus niger, that produced lapachol and caused DNA breakdown in yeast. Conventional fermentation in potato dextrose broth followed by methanol extraction and chromatography yielded lapachol identified by thin-layer chromatography (TLC) and color reactions. No high performance liquid chromatography-mass spectrometry (HPLC-MS) or spectroscopic identifications were reported, ${ }^{90}$ and interestingly the same group published a similar paper but in 2011 covering the same work, ${ }^{91}$ so the validity of this data might be in question. Though the papers were cited in a recent major review of fungal epi/endophyte production by Nicoletti and Fiorentino ${ }^{92}$ in 2015, the 2011 paper is in a journal cited on Beall's List, so the reader may need to consider the validity of the data. Although fungal endophytes might be a source of this compound, until more definitive chemical data as to the identities of the materials isolated is reported in the literature, these reports have to be treated with significant caution.<smiles>CC(C)=CCC1=C(O)C(=O)c2ccccc2C1=O</smiles>

29. Lapachol<smiles>CC1(C)CCC2=C(O1)c1ccccc1C(=O)C2=O</smiles>

30. $\beta$-Lapachone<smiles>[R]Cc1nc2c(o1)-c1ccccc1C(=O)C2=O</smiles>

31. Compound 3k; $\mathrm{R}=4$-benzylpiperazin-1-yl<smiles>O=C1C(O)=C(C2CCC(c3ccc(Cl)cc3)CC2)C(=O)c2ccccc21</smiles>

32. Atovaquone

Figure 4. Compounds 29 to 32; lapachol and derivatives. 


\section{Potential Areas for Future Consideration from a Biodiversity Perspective}

As can be seen from this review, Brazil has superb biodiversity, particularly with respect to plant and marine resources that has barely been touched in comparison to what is there. The work that has already been reported has been covered quite well in the citations given above and in particular, it is recommended that the report by Joly ${ }^{93}$ be read for its insight in the establishment of BIOTA/FAPESP and the work funded up to the date of the publication.

In addition to Joly's review, Bolzani and co-workers ${ }^{94}$ over the years have demonstrated the natural products chemistry of (mainly) plant materials in São Paulo State and also in other areas of Brazil, and has deposited the structures of the compounds isolated and identified into the ZINC database where the results are available for use in bioinformatics based analyses.

In the marine area, Berlinck and co-workers ${ }^{67-70,95}$ published a significant number of papers on the subject of marine metabolites but over the past few years, have moved into the investigation of both microbes in and on marine invertebrates. These are not formally endophytes in the sense that this term is used in the plant kingdom, but are more similar to epiphytes. They have significant publications demonstrating the complexity, and at times, the relative simplicity of molecules from such natural sources, in addition to state of the art investigations into the genomics of marine-sourced microbes and relationships to secondary metabolites.

In addition to the more "genomic" types of publications, the potential for secondary metabolites to provide new treatments for parasitic diseases have also been discussed. An example would be the 2011 paper $^{96}$ discussing the potential of marine-sourced antileishmanial compounds, and work reported from Finland where novel agents against both leishmania and Chagas disease have been derived from simple diterpenes that are known from plant and marine sources, the abietane amides with "compound 10" (33) in the paper by Pittimaa et al..${ }^{97}$ giving the best bioactivities against these two parasites.

Thus Brazilian scientists and their collaborators are fully cognizant of the possibilities that Brazil's biodiversity holds for discovery of novel treatments against diseases that affect Brazil in particular, but that also will have potential for others. In addition, as befits the country that hosted the Rio Earth Summit that led to the Convention on Biological Diversity Brazilian scientists are heavily involved in making certain that development of biodiversity is done under conditions that benefit Brazil, and other countries whose flora and fauna are being investigated.

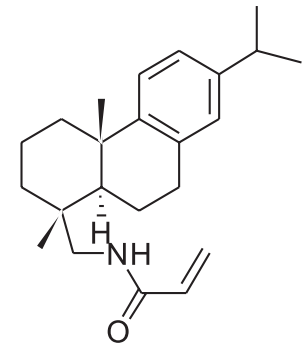

33. "Compound 10"

Figure 5. Compound 33; antiparasitic abietane derivative.

Two recent reviews ${ }^{98,99}$ demonstrate how this "stewardship of resources" is being approached. The first is a publication directed more at the marine environment by Barber et al. ${ }^{98}$ whereas the second is directed more at plants and the potential for biopiracy. ${ }^{99}$ Both of these reviews are essential reading for anyone who wishes to investigate biodiversity wherever it is on the planet. However, Brazil and more particularly, São Paulo State as exemplified by FAPESP, has shown how it is open to joint investigations competitively funded by the US Government (NIH and NSF) and FAPESP into insect-microbe symbioses (the ICBG Program referred to earlier). Although the USA has never ratified the $\mathrm{CBD}$, this joint program demonstrated the willingness of Brazilian organizations to collaborate on a 50:50 basis investigating specific aspects of biodiversity that augurs well for further collaborations.

Thus encouragement should be given to Brazilian scientists and their collaborators irrespective of their backgrounds, to investigate the immense resources in Brazilian biodiversity. It is hoped that the legal systems in the various countries involved will permit such collaborations to succeed, as no one country, including the USA, has the necessary resources to investigate, discover and then develop, agents based on natural product discoveries as novel treatments for the manifold diseases of man.

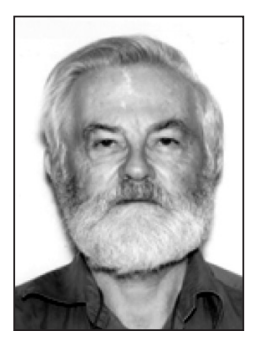

David J. Newman (DPhil, Sussex, 1968, microbial chemistry) retired in January 2015 as Chief of the Natural Products Branch (NPB) at the US NCI. He came to the USA in 1968 and following 23 years in academia and industry, joined the NPB in 1991, becoming Chief in 2005. He has over 175 publications covering natural products as drugs or leads thereto. He was President (2012-2013) of the American Society of Pharmacognosy (ASP) and was elected a fellow of the ASP 
in 2014. He currently has a small consulting company in the US covering drug discovery.

\section{References}

1. Bouchard, C.; Compt. Rend. Soc. Biol. 1884, 8, 665.

2. Tigerstedt, R.; Bergman, P. G.; Skand. Arch. Physiol. 1898, 8, 223.

3. Skeggs, L. T.; Dorer, F. E.; Kahn, J. R.; Lentz, K. E.; Levin, M. In Biochemical Regulation of Blood Pressure; Soffer, R., ed.; John Wiley \& Sons, Inc.: Hoboken, 1981, p. 3.

4. Ferreira, S. H.; Rocha e Silva, M.; Biochem. Pharmacol. 1962, $11,1123$.

5. Ferreira, S. H.; Bartelt, D. C.; Greene, L. J.; Biochemistry 1970, 9, 2583.

6. Ondetti, M. A.; Williams, N. J.; Sabo, E. F.; Pluscec, J.; Weaver, E. R.; Kocy, O.; Biochemistry 1971, 10, 4033.

7. Kato, H.; Suzuki, T.; Proc. Jpn. Acad. 1970, 46, 176.

8. Hooper, N. M.; Turner, A. J.; Nat. Struct. Biol. 2003, 10, 155.

9. Patchett, A. A.; Harris, E.; Tristram, E. W.; Wyvratt, M. J.; Wu, M. T.; Taub, D.; Peterson, E. R.; Ikeler, T. J.; ten Broeke, J.; Payne, L. G.; Ondeyka, D. L.; Thorsett, E. D.; Greenlee, W. J.; Lohr, N. S.; Hoffsommer, R. D.; Joshua, H.; Ruyle, W. V.; Rothrock, J. W.; Aster, S. D.; Maycock, A. L.; Robinson, F. M.; Hirschmann, R.; Sweet, C. S.; Ulm, E. H.; Gross, D. M.; Vassil, T. C.; Stone, C. A.; Nature 1980, 288, 280.

10. Patchett, A. A.; Cordes, E. H.; Adv. Enzymol. Relat. Areas Mol. Biol. 1985, 57, 1.

11. Acharya, K. R.; Sturrock, E. D.; Riordan, J. F.; Ehlers, M. R. W.; Nat. Rev. Drug Discovery 2003, 2, 891.

12. Danilov, S. M.; Gordon, K.; Nesterovitch, A. B.; Lünsdorf, H.; Chen, Z.; Castellon, M.; Popova, I. A.; Kalinin, S.; Mendonca, E.; Petukhov, P. A.; Schwartz, D. E.; Minshall, R. D.; Sturrock, E. D.; PLoS One 2011, 6, e25952.1.

13. Masuyer, G.; Schwager, S. L. U.; Sturrock, E. D.; Isaac, R. E.; Acharya, K. R.; Sci. Rep. 2012, 2, 717.

14. Kuba, K.; Imai, Y.; Penninger, J. M.; Circ. J. 2013, 77, 301.

15. Luft, F. C.; J. Mol. Med. 2014, 92, 793.

16. Bernstein, K. E.; Ong, F. S.; Blackwell, W.-L. B.; Shah, K. H.; Giani, J. F.; Gonzalez-Villalobos, R. A.; Shen, X. Z.; Fuchs, S.; Pharmacol. Rev. 2013, 65, 1.

17. Regulska, K.; Stanisz, B.; Regulski, M.; Murias, M.; Drug Discovery Today 2014, 19, 1731.

18. Pavan, M.; Bo, G.; Mem. Soc. Entomol. Ital. 1952, 31, 67.

19. Cressey, B. D.; Paniz-Mondolfi, A. E.; Rodríguez-Morales, A. J.; Ayala, J. M.; da Silva, A. A. A.; Wilderness Environ. Med. 2013, 24, 124.

20. Cardani, C.; Ghiringhelli, D.; Yondelli, R.; Quilioo, A.; Tetrahedron Lett. 1965, 6, 2537.

21. Matsumoto, T.; Yanagiya, M.; Maeno, S.; Yasuda, S.; Tetrahedron Lett. 1968, 9, 6297.
22. Jewett, J. C.; Rawal, V. H.; Angew. Chem., Int. Ed. 2007, 46, 6502 .

23. Wu, F.; Green, M. E.; Floreancig, P. E.; Angew. Chem., Int. Ed. 2011, 50, 1131.

24. Perry, N. B.; Blunt, J. W.; Munro, M. H. G.; Pannell, L. K.; J. Am. Chem. Soc. 1988, 110, 4850.

25. Perry, N. B.; Blunt, J. W.; Munro, M. H. G.; Thompson, A. M.; J. Org.Chem. 1990, 55, 223.

26. Price, C. A.; Lynch, E. M.; Bowie, B. A.; Newman, D. J.; J. Antibiot. 1981, 34, 118.

27. Frincke, J. M.; Faulkner, D. J.; J. Am. Chem. Soc. 1982, 104, 265.

28. Kellner, R. L. L.; Entomol. Exp. Appl. 1999, 93, 41.

29. Kellner, R. L. L.; J. Insect Physiol. 2001, 47, 475.

30. Vuong, D.; Capon, R. J.; Lacey, E.; Gill, J. H.; Heiland, K.; Friedel, T.; J. Nat. Prod. 2001, 64, 640.

31. Paul, G. K.; Gunasekera, S. P.; Longley, R. E.; Pomponi, S. A.; J. Nat. Prod. 2002, 65, 59.

32. Kellner, R. L. L.; Chemoecology 2002, 12, 133.

33. Piel, J.; Proc. Natl. Acad. Sci. USA 2002, 99, 14002.

34. Piel, J.; Wen, G.; Platzer, M.; Hui, D.; ChemBioChem 2004, 5, 93.

35. Piel, J.; Hui, D.; Wen, G.; Butzke, D.; Platzer, M.; Fusetani, N.; Matsunaga, S.; Proc. Natl. Acad. Sci. USA 2004, 101, 16222.

36. Piel, J.; Hofer, I.; Hui, D.; J. Bacteriol. 2004, 186, 1280.

37. Piel, J.; Butzke, D.; Fusetani, N.; Hui, D.; Platzer, M.; Wen, G.; Matsunaga, S.; J. Nat. Prod. 2005, 68, 472.

38. Kador, M.; Horn, M. A.; Dettner, K.; FEMS Microbiol. Lett. 2011, 319, 73.

39. Wilson, M. C.; Piel, J.; Chem. Biol. 2013, 20, 636.

40. Bewley, C. A.; Faulkner, D. J.; Angew. Chem., Int. Ed. 1998, 37, 2162.

41. Wilson, M. C.; Mori, T.; Ruckert, C.; Uria, A. R.; Helf, M. J.; Takada, K.; Gernert, C.; Steffens, U. A. E.; Heycke, N.; Schmitt, S.; Rinke, C.; Helfrich, E. J. N.; Brachmann, A. O.; Gurgui, C.; Wakimoto, T.; Kracht, M.; Crusemann, M.; Hentschel, U.; Abe, I.; Matsunaga, S.; Kalinowski, J.; Takeyama, H.; Piel, J.; Nature 2014, 506, 58.

42. Wakimoto, T.; Egami, Y.; Nakashima, Y.; Wakimoto, Y.; Mori, T.; Awakawa, T.; Ito, T.; Kenmoku, H.; Asakawa, Y.; Piel, J.; Abe, I.; Nat. Chem. Biol. 2014, 10, 648.

43. Morinaka, B. I.; Vagstad, A. L.; Helf, M. J.; Gugger, M.; Kegler, C.; Freeman, M. F.; Bode, H. B.; Piel, J.; Angew. Chem., Int. Ed. 2014, 53, 8503.

44. Freeman, M. F.; Vagstad, A. L.; Piel, J.; Curr. Opin. Chem. Biol. 2016, 31,8 .

45. Kampa, A.; Gagunashvili, A. N.; Gulder, T. A. M.; Morinaka, B. I.; Daolio, C.; Godejohann, M.; Miao, V. P. W.; Piel, J.; Andrésson, Ó. S.; Proc. Natl. Acad. Sci. USA 2013, 110, E3129.

46. Jiang, X.; Williams, N.; de Brabander, J. K.; Org. Lett. 2007, 9, 227. 
47. Nishii, Y.; Higa, T.; Takahashi, S.; Nakata, T.; Tetrahedron Lett. 2009, 50, 3597.

48. Wan, S.; Wu, F.; Rech, J. C.; Green, M. E.; Balachandran, R.; Horne, W. S.; Day, B. W.; Floreancig, P. E.; J. Am. Chem. Soc. 2011, 133, 16668.

49. Wu, C.-Y.; Feng, Y.; Cardenas, E. R.; Williams, N.; Floreancig, P. E.; de Brabander, J. K.; Roth, M. G.; J. Am. Chem. Soc. 2012, 134, 18998.

50. Mosey, R. A.; Floreancig, P. E.; Nat. Prod. Rep. 2012, 29, 980.

51. Floreancig, P. E. In Strategies and Tactics in Organic Synthesis, vol. 10; Harmata, M., ed.; Elsevier: Amsterdam, 2014, p. 184.

52. Uesugi, S.; Watanabe, T.; Imaizumi, T.; Ota, Y.; Yoshida, K.; Ebisu, H.; Chinen, T.; Nagumo, Y.; Shibuya, M.; Kanoh, N.; Usui, T.; Iwabuchi, Y.; J. Org. Chem. 2015, 80, 12333.

53. Vieira, J. S.; Ribeiro-Costa, C. S.; Caron, E.; Rev. Bras. Entomol. 2014, 58, 244.

54. Kim, K. H.; Ramadhar, T. R.; Beemelmanns, C.; Cao, S.; Poulsen, M.; Currie, C. R.; Clardy, J.; Chem. Sci. 2014, 5, 4333.

55. Oh, D.-C.; Poulsen, M.; Currie, C. R.; Clardy, J.; Nat. Chem. Biol. 2009, 5, 391.

56. Oelke, A. J.; France, D. J.; Hofmann, T.; Wuitschike, G.; Ley, S. V.; Nat. Prod. Rep. 2011, 28, 1445.

57. Sit, C. S.; Ruzzini, A. C.; van Arnam, E. B.; Ramadhar, T. R.; Currie, C. R.; Clardy, J.; Proc. Natl. Acad. Sci. USA 2015, 112, 13150.

58. Miller, E. D.; Kauffman, C. A.; Jensen, P. R.; Fenical, W.; J. Org. Chem. 2007, 72, 323.

59. Schmidt, M. A.; Cell. Microbiol. 2010, 12, 1544.

60. https://projectreporter.nih.gov/project_info_description. cfm?aid=8785542\&icde=21447093 accessed in July 2016.

61. Menezes, C.; Vollet-Neto, A.; Marsaioli, A. J.; Zampieri, D.; Cardoso Fontoura, I.; Luchessi, A. D.; Imperatriz-Fonseca, V. L.; Curr. Biol. 2015, 25, 2851.

62. Oldroyd, B. P.; Aanen, D. K.; Curr. Biol. 2015, 25, R1072.

63. Beemelmanns, C.; Guo, H.; Rischer, M.; Poulsen, M.; Beilstein J. Org. Chem. 2016, 12, 314.

64. Becker, M. H.; Walke, J. B.; Cikanek, S.; Savage, A. E.; Mattheus, N.; Santiago, C. N.; Minbiole, K. P. C.; Harris, R. N.; Belden, L. K.; Gratwicke, B.; Proc. R. Soc. B 2015, 282, 20142881.

65. Belden, L. K.; Hughey, M. C.; Rebollar, E. A.; Umile, T. P.; Loftus, S. C.; Burzynski, E. A.; Minbiole, K. P. C.; House, L. L.; Jensen, R. V.; Becker, M. H.; Walke, J. B.; Medina, D.; Ibáñez, R.; Harris, R. N.; Front. Microbiol. 2015, 6, 1171.

66. http://web.archive.org/web/20120419075053/http://earthtrends. wri.org/text/coastal-marine/variable-61.html, accessed in August 2016.

67. Trindade-Silva, A. E.; Rua, C. P. J.; Andrade, B. G. N.; Vicente, A. C. P.; Silva, G. G. Z.; Berlinck, R. G. S.; Thompson, F. L.; Appl. Environ. Microbiol. 2013, 79, 1598.
68. Rua, C. P. J.; Trindade-Silva, A. E.; Appolinario, L. R.; Venas, T. M.; Garcia, G. D.; Carvalho, L. S.; Lima, A.; Kruger, R.; Pereira, R. C.; Berlinck, R. G. S.; Valle, R. A. B.; Thompson, C. C.; Thompson, F.; PeerJ 2014, 2, e419.

69. Kossuga, M. H.; Romminger, S.; Xavier, C.; Milanetto, M. C.; do Valle, M. Z.; Pimenta, E. F.; Morais, R. P.; de Carvalho, E.; Mizuno, C. M.; Coradello, L. F. C.; Barroso, V. M.; Vacondio, B.; Javaroti, D. C. D.; Seleghim, M. H. R.; Cavalcanti, B. C.; Pessoa, C.; Moraes, M. O.; Lima, B. A.; Gonçalves, R.; Bonugli-Santos, R. C.; Sette, L. D.; Berlinck, R. G. S.; Rev. Bras. Farmacogn. 2012, 22, 257.

70. Ioca, L. P.; Allard, P.-M.; Berlinck, R. G. S.; Nat. Prod. Rep. 2014, 31, 646.

71. Regasini, L. O.; Vieira Jr., G. M.; Fernandes, D. C.; Bolzani, V. D. S.; Cavalheiro, A. J.; Silva, D. H. S.; J. Chil. Chem. Soc. 2009, 54, 218.

72. Regasini, L. O.; Fernandes, D. C.; Castro-Gamboa, I.; Silva, D. H. S.; Furlan, M.; Bolzani, V. S.; Barreiro, E. J.; CardosoLopes, E. M.; Young, M. C. M.; Torres, L. B.; Vellosa, J. C. R.; de Oliveira, O. M. M.; Quim. Nova 2008, 31, 802.

73. Silva, R.; Lopes, N. P.; Silva, D. B.; Planta Med. 2016, 82, 671.

74. Regasini, L. O.; Castro-Gamboa, I.; Silva, D. H. S.; Furlan, M.; Barreiro, E. J.; Ferreira, P. M. P.; Pessoa, C.; Costa-Lotufo, L. V.; de Moraes, M. O.; Young, M. C. M.; Bolzani, V. D. S.; J. Nat. Prod. 2009, 72, 473.

75. Carnevale Neto, F.; Pilon, A. C.; Bolzani, V. S.; Castro-Gamboa, I.; Phytochem. Rev. 2013, 12, 121.

76. Cruz, L. R.; Spangenberg, T.; Lacerda, M. V. G.; Wells, T. N. C.; Malar. J. 2013, 12, 168.

77. Suffness, M.; Douros, J. In Anticancer Agents Based on Natural Product Models; Cassady, J. M.; Douros, J. D., eds.; Academic Press: New York, 1980, p. 465.

78. Ravelo, A. G.; Estevez-Braun, A.; Chavez-Orellana, H.; PerezSacau, E.; Mesa-Siverio, D.; Curr. Top. Med. Chem. 2004, 4, 241.

79. Shapiro, G. I.; Ryan, D. P.; Appleman, L. J.; Zhu, A. X.; Clark, J. W.; Berkenblit, A.; Cunningham, C. C.; Yagovane, D. M.; Dombal, G. E.; Li, C. J.; Eder, J. P.; Supko, J. G.; Proc. Am. Assoc. Cancer Res. (AACR) 2006, 47, Abst LB-142.

80. Hartner, L. P.; Rosen, L.; Hensley, M.; Mendelson, M.; Staddon, A. P.; Chow, W.; Kovalyov, O.; Ruka, W.; Skladowski, K.; Jagiello-Gruszfeld, A.; Byakhov, M.; J. Clin. Oncol. 2007, 25, Abst 20521.

81. Khong, H. T.; Dreisbach, L.; Kindler, H. L.; Trent, D. F.; Jeziorski, K. G.; Bonderenko, I.; Popiela, T.; Yagovane, D. M.; Dombal, G.; J. Clin. Oncol. 2007, 25, Abst 15017.

82. Wellington, K. W.; RSC Adv. 2015, 5, 20309.

83. Bian, J.; Qian, X.; Deng, B.; Xu, X.; Guo, X.; Wang, Y.; Li, X.; Sun, H.; You, Q.; Zhang, X.; RSC Adv. 2015, 5, 49471.

84. Li, X. B., J.; Wang, N.; Qian, X.; Gu, J.; Mu, T.; Fan, J.; Yang, X.; Li, S.; Yang, T.; Sun, H.; You, Q.; Zhang, X.; Bioorg. Med. Chem. 2016, 24, 1006. 
85. Looareesuwan, S.; Chulay, J. D.; Canfield, C. J.; Hutchinson, D. B. A.; Am. J. Trop. Med. Hyg. 1999, 60, 533.

86. Dohn, M. N.; Weinberg, W. G.; Torres, R. A.; Follansbee, S. E.; Caldwell, P. T.; Scott, J. D.; Gathe, J. C.; Haghighat, D. P.; Sampson, J. H.; Spotkov, J.; Deresinski, S. C.; Meyer, R. D.; Lancaster, D. J.; Ann. Intern. Med. 1994, 121, 174.

87. Krause, P. J.; Lepore, T.; Sikand, V. K.; Gadbaw Jr., J.; Burke, G.; Telford 3rd, S. R.; Brassard, P.; Pearl, D.; Azlanzadeh, J.; Christianson, D.; McGrath, D.; Spielman, A.; N. Engl. J. Med. 2000, 343, 1454.

88. Epifano, F.; Genovese, S.; Fiorito, S.; Mathieu, V.; Kiss, R.; Phytochem. Rev. 2014, 13, 37.

89. Otten, S.; Rosazza, J. P.; Appl. Environ. Microbiol. 1979, 38, 311.

90. Channabasava; Govindappa, M.; Bangladesh J. Pharmacol. 2014, 9, 129.

91. Sadananda, T. S.; Nirupama, R.; Chaithra, K.; Govindappa, M.; Chandrappa, C. P.; Vinay, R. B.; J. Med. Plants Res. 2011, 5 , 3643.

92. Nicoletti, R.; Fiorentino, A.; Agriculture 2015, 5, 918.

93. Joly, C. A. In Applied Ecology and Human Dimensions in Biological Conservation; Verdade, L. M.; Lyra-Jorge, M. C.; Pina, C. I., eds.; Springer-Verlag: Heidelberg, 2014, p. 211.

94. Valli, M.; dos Santos, R. N.; Figueira, L. D.; Nakajima, C. H.; Castro-Gamboa, I.; Andricopulo, A. D.; Bolzani, V. S.; J. Nat. Prod. 2013, 76, 439.
95. Menezes, C. B. A.; Bonugli-Santosa, R. C.; Miqueletto, P. B.; Passarini, M. R. Z.; Silva, C. H. D.; Justo, M. R.; Leal, R. R.; Fantinatti-Garboggini, F.; Oliveira, V. M.; Berlinck, R. G. S.; Sette, L. D.; Microbiol. Res. 2010, 165, 466.

96. Tempone, A. G.; de Oliveira, C. M.; Berlinck, R. G. S.; Planta Med. 2011, 77, 572.

97. Pirttimaa, M.; Nasereddin, A.; Kopelyanskiy, D.; Kaiser, M.; Yli-Kauhaluoma, J.; Oksman-Caldentey, K.-M.; Brun, R.; Jaffe, C. L.; Moreira, V. M.; Alakurtti, S.; J. Nat. Prod. 2016, 79, 362.

98. Barber, P. H.; Ablan-Lagman, M. C. A.; Ambariyanto; Berlinck, R. G. S.; Cahyani, D.; Crandall, E. D.; Ravago-Gotanco, R.; Juinio-Meñez, M. A.; Mahardika, I. G. N.; Shanker, K.; Starger, C. J.; Toha, A. H. A.; Anggoro, A. W.; Willette, D. A.; Bull. Mar. Sci. 2014, 90, 187.

99. Efferth, T.; Banerjee, M.; Paul, N. W.; Abdelfatah, S.; Arend, J.; Elhassan, G.; Hamdoun, S.; Hamm, R.; Hong, C.; Kadioglu, O.; Nass, J.; Ochwangi, D.; Ooko, E.; Ozenver, N.; Saeed, M. E. M.; Schneider, M.; Seo, E.-J.; Wu, C.-F.; Yan, G.; Zeino, M.; Zhao, Q.; Abu-Darwish, M. S.; Andersch, K.; Alexie, G.; Bessarab, D.; Bhakta-Guha, D.; Bolzani, V.; Dapat, E.; Donenko, F. V.; Efferth, M.; Greten, H. J.; Gunatilaka, L.; Hussein, A. A.; Karadeniz, A.; Khalid, H. E.; Kuete, V.; Lee, I.-S.; Liu, L.; Midiwo, J.; Mora, R.; Nakagawa, H.; Ngassapa, O.; Noysang, C.; Omosa, L. K.; Roland, F. H.; Shahat, A. A.; Saab, A.; Saeed, E. M.; Shan, L.; Titinchi, S. J. J.; Phytomedicine 2016, 23, 166.

Submitted: June 13, 2016

Published online: August 3, 2016 